\title{
Level of Curriculum Implementation in Public Preschools of Ozamiz City and Tangub City Divisions
}

\author{
Perlito D. Jomuad \\ College of Education, Misamis University, Ozamiz City, Philippines \\ Corresponding author: email - mtjomuad@yahoo.com
}

\begin{abstract}
Evaluation of early childhood education is important to the learning outcomes of preschoolers. This study assessed the level of curriculum implementation in public schools of Ozamiz City and Tangub City divisions. Misamis Occidental, Philippines in terms of physical, personal, personalsocial, cognitive, creative-aesthetic, and socio-emotional development activities of preschoolers. A researcher-constructed questionnaire was administered to 66 respondents drawn randomly from a population of 92 school teachers. Results showed that the teachers perceived some levels of effective implementation of the physical, cognitive, personal-social, and socio-emotional aspects of the early childhood education curriculum. Teachers were able to teach the preschoolers how to develop and take care of their physical bodies, relate themselves to others especially to classmates and teachers, develop their thinking skills through play and interaction, appreciate beauty and order, and adjust to school life and to the people around them. Relative to other development aspects of preschools, creativeaesthetic development activities have to be given more attention by teachers. Class activities related to creativity, beauty and order have to be improved.
\end{abstract}

Keywords: cognitive, creative-aesthetic, physical, preschoolers, teachers 


\section{Introduction}

Preschool education is a package of relevant learning experiences as keys to the subsequent academic successes of learners (Seay, 2012). In fact, the preschool curriculum should be standardsbased to provide learning experiences dedicated to the children's social, emotional and cognitive development (Mckie et al., 2012). There should be interrelatedness of all learning areas, and no learning area should be taught in isolation (Conyers, 2012). The ECE learning areas include activities that should develop the child's communication skills in English and Filipino, numeracy skills, sensory-perceptual skills, socio-emotional skills, and motor and creative skills.

Early childhood experiences can develop a love of school. Children actively construct knowledge within a social context (Mcafee \& Leong, 2011). Preschoolers interact with peers to develop their cognitive abilities (Mawson, 2011). Thus, they should interact with others as thinking also develops through social interaction (Salmon \& Lucas, 2011). Also, their interactions with others, especially with parents, can influence their success once they start formal education (Di Santo, 2012). McCray and Chen (2012) suggested that early intervention has good effects on the learning of children.

The quality of the teaching and learning environment matters for children's development (Patterson, 2008). For example, it is vital for a teacher or teacher-surrogate to discipline a child, and allow him to express and explore after all he is capable of doing self-regulation even if he is still young (Lynch \& Batal, 2012). Glazzard et al. (2010) posited that effective teachers consider the children's interest as a starting point for developing and assessing specific learning competences within their setting. It is also important that preschool teachers teach the young how to pray and show respect to the people around them. The success in life may depend on how an emotion is developed in their younger days (Jacob et al., 2012). The children's present academic and social development is influenced by the quality of care given to them in their younger years (Ma et al., 2011).

In the Philippines, the Department of Education through its DECS Order series of 19898 stipulated that the goal of preschool education or early childhood education (ECE) is to develop the child in his physical, social, moral, spiritual, emotional and cognitive 
aspects so that he may be better prepared to adjust and cope with life situations within the context of his experience. The ECE curriculum has been focused on areas toward the child's total development. A child needs to have time to move and play in the outdoors (Rooprarine \& Johnson, 2009).

Assessing the level of curriculum implementation in preschools is needed to determine the success of the program. This study evaluated the extent for which the ECE curriculum had been effectively implemented. The evaluation pointed on the teachers' perceptions on their implementation of the ECE curriculum that focused on the physical, personal-social, cognitive, creative-aesthetic and socio-emotional aspects of the children's development.

\section{Materials and Methods}

A survey was conducted using a researcher-constructed questionnaire administered to 66 willing respondents randomly drawn from a total of 92 preschool teachers. Face validity was achieved before reliability analysis was performed. The study was conducted in Ozamiz City and Tangub City Divisions in the Province of Misamis Occidental, Philippines. Permission to administer the questionnaires was sought from the superintendents of the two divisions.

The questionnaire consisted of statements for pre-school development activities with responses as follows: Always (5), Often (4), Sometimes (3), Seldom (2), and, Never (1). Weighted Mean (WM) was computed per item and per area of development activity (physical development, personal-social development, cognitive development, creative-aesthetic development and socio-emotional development) which was interpreted as follows: $4.20-5.00-$ Very High Implementation; (3.4 - 4.19) - High Implementation; (2.6 $3.39)$ - Average Implementation; $(1.8$ - 2.59) - Low Implementation; and $(1.0-1.79)$ - Very Low Implementation.

\section{Results and Discussion}

Table 1 presents the teachers' perceptions on their level of implementation relative to the physical development activities of the ECE curriculum. As shown, the physical development activities were 
always performed in the class, signifying that the level of curriculum implementation was very high. Teachers emphasized play activities and gave importance to manipulative activities such as games and simple work that would develop physical fitness.

\section{Table 1. Level of implementation of preschool curriculum activities as to physical development of preschoolers.}

\begin{tabular}{lcc}
\hline \hline Physical Development Activities & Weighted Mean & Interpretation \\
\hline Emphasizes play activities. & 4.65 & $\mathrm{VH}$ \\
Gives importance to manipulative activities like & 4.80 & $\mathrm{VH}$ \\
$\begin{array}{l}\text { games, simple work and those that develop fitness. } \\
\text { Overall Weighted Mean }\end{array}$ & 4.73 & $\mathrm{VH}$ \\
\hline \hline
\end{tabular}

VH - Very High

Play is a medium for learning (Ernest, 2012). Kohler et al. (2012) recommended play in the learning process for small and young children. The child is an active participant in learning so play should be given emphasis as a means of learning (Horn et al., 2012). Children should be made to play and explore since playful and interesting activities support their literacy development (Yopp \& Yopp, 2000). Games and exploration are socialization activities that are given more emphasis to allow small children to strengthen their physical bodies and at the same time establish contact with other pupils. By contrast, academic activities like reading, writing and problem solving are not the primary activities in this stage. Children acquire knowledge if they interact with others (Freeman \& Karlsson, 2012). At this stage, they are immature enough to tackle activities which demand more thinking and imagination.

Teachers should refrain from doing rigid instruction in the class, since this kind of teaching would seem boring and frustrating to small and young children. Even if preschoolers are performing cognitive activities, they should feel that they are only playing, and later on they will learn to love academic activities. Besides, teachers should consider the children as active recipients of any pedagogical practice so that learning will become more meaningful (Anderson et al., 2012). 
As shown in Table 2, the level of implementation of personalsocial development activities was very high. Developing health habits had the highest weighted mean and developing independence in dressing, eating, sleeping and using of the comfort room had the lowest weighted mean. Teachers reported that they taught their pupils how to develop health habits, namely, becoming independent in dressing up, eating, sleeping, and in using the comfort rooms. They emphasized how children should relate with teachers, peers, and other people through group play and/or interaction. They also trained them how to follow rules and routine activities.

It is basic in preschool education to develop health habits among the children. As young as they are, children are taught to be clean and neat all the time. They are also taught how to use the comfort room if ever they want to use it. The teacher who stands as a guide gives the children some important hints in performing a quite complex activity. However, in performing all these activities, children should be properly guided since they have faith in their own abilities (Parks and Rhoads, 2012). Sometimes, they want autonomy in performing certain tasks where they do not like adult assistance or supervision.

Table 2. Level of implementation of preschool curriculum activities as to personal social development of preschoolers.

\begin{tabular}{lcc}
\hline \hline Personal-Social Development Activities & $\begin{array}{c}\text { Weighted } \\
\text { Mean }\end{array}$ & Interpretation \\
\hline $\begin{array}{l}\text { Develops health habits. } \\
\text { Develops independence in dressing, eating, sleeping, } \\
\text { and using of the comfort room. }\end{array}$ & 4.70 & $\mathrm{VH}$ \\
$\begin{array}{l}\text { Emphasizes how to relate with teachers, peers and } \\
\text { other people through group play and/or interaction. }\end{array}$ & 4.55 & $\mathrm{VH}$ \\
$\begin{array}{l}\text { Deals with the development of the ability to follow } \\
\text { rules and routine. }\end{array}$ & 4.61 & $\mathrm{VH}$ \\
\begin{tabular}{l} 
Overall Weighted Mean \\
\hline
\end{tabular} & 4.59 & $\mathrm{VH}$ \\
\hline
\end{tabular}

VH - Very High

In Table 3, the overall weighted mean reveals that the level of implementation of cognitive activities was very high, with developing numeracy skills obtaining the highest weighted mean, and developing sensory-perceptual skills getting the lowest weighted mean. This 
suggests that teachers endeavoured to develop in their pupils the art of communication and the art of numeracy.

Even if physical and social activities are given more emphasis in early childhood education, there are times when children have to express their language skills and do mathematics wherein children are taught to identify numbers and to count. Children come to school to learn what is difficult to learn indirectly through informal interactions with language in their environment (Holmes et al., 2012). There are simple activities in communication and numeracy that preschool children perform with the teachers' careful supervision.

Table 3. Level of implementation of preschool curriculum activities as to cognitive development of preschoolers.

\begin{tabular}{lcc}
\hline \hline Cognitive Development Activities & $\begin{array}{c}\text { Weighted } \\
\text { Mean }\end{array}$ & Interpretation \\
\hline Develops children in the art of communication. & 4.64 & VH \\
Develops children in the art of numeracy. & 4.80 & VH \\
Develops children's sensory-perceptual concepts and & 4.48 & VH \\
skills. & & \\
Overall Weighted Mean & 4.64 & VH \\
\hline \hline
\end{tabular}

VH - Very High

The level of implementation of creative-aesthetic development activities was high (Table 4). The highest weighted mean was on developing children to explore music, while the lowest weighted mean was on the making of poems and stories. Teachers were able to teach the children to explore sound, music and rhythm, emphasize the use of media instruction like the use of crayons and paints, and stress the creation of poems, stories and dramatization.

Even if preschool children are still young and immature, they should be taught to appreciate beauty and order since children are art creators (Binder \& Kotsopoulus, 2011). They should be taught to appreciate music, sounds and rhythm. It is important that singing, dancing and painting, among others are emphasized in the class. Children are encouraged to sing and dance not only to exercise their physical bodies but also to stimulate their imagination. One emphasis of preschool education is the development of the whole personality of the child, and this could be attained by providing a variety of interesting activities like playing and exploring things. Children at this age like to see and view colorful pictures. During this stage, children's 
attention is directed to pictures more than to text especially if the pictures they see are appealing to their sight (Crabb and Marciano, 2011).

Table 4. Level of implementation of preschool curriculum activities as to creative-aesthetic development of preschoolers.

\begin{tabular}{lcc}
\hline \hline Creative-Aesthetic Development Activities & Weighted Mean & Interpretation \\
\hline $\begin{array}{l}\text { Develops children to explore sound, music and } \\
\text { rhythm. }\end{array}$ & 4.36 & $\mathrm{VH}$ \\
$\begin{array}{l}\text { Emphasizes the use of media instruction like the } \\
\text { use of crayons and paints. }\end{array}$ & 4.26 & $\mathrm{VH}$ \\
$\begin{array}{l}\text { Stresses the creation of poems, stories and } \\
\text { dramatization. }\end{array}$ & 3.91 & $\mathrm{H}$ \\
Overall Weighted Mean & 4.18 & $\mathrm{H}$ \\
\hline \hline
\end{tabular}

VH - Very High, $\mathrm{H}$ - High

The overall weighted mean reveals that the socio-emotional development activities were always performed in the class, suggesting that the level of implementation was very high. The development of behaviors for health habits obtained the highest weighted mean and providing a variety of activities for the development of the children (Table 5). This finding supports Section 3 of RA 8990 which states that the objective of the National System for Early Childhood Care and Development is to enhance the physical, social, emotional, cognitive, psychological, spiritual and language development of young children (Bilbao et al., 2006).

\section{Table 5. Level of implementation of preschool curriculum activities as to socio-emotional development of preschoolers.}

\begin{tabular}{lll}
\hline \hline Socio-Emotional Development Activities & Weighted Mean & Interpretation \\
\hline $\begin{array}{l}\text { Provides activities that contribute to the development } \\
\text { of the wholesome personality of the child. }\end{array}$ & $\mathrm{VH}$ \\
$\begin{array}{l}\text { Develops skills and behaviors towards the } \\
\text { development of health habits. }\end{array}$ & $\mathrm{VH}$ \\
$\begin{array}{l}\text { Exposes children to actual situations and vicarious } \\
\text { experiences that will help them develop a sense of } \\
\text { responsibility and awareness of right and wrong. } \\
\text { Overall Weighted Mean }\end{array}$ & $\mathrm{VH}$ \\
\hline \hline
\end{tabular}

VH - Very High 
Table 6 presents the summary on the level of implementation of preschool curriculum activities, and the weighted mean manifests that the level of implementation is very high. The study was limited to determining the level of curriculum implementation in Early Childhood Education in the aspects of physical, personal-social, cognitive, creative-aesthetic and socio-emotional development, and this could be determined using the weighted mean.

\section{Table 6. Summary on the level of implementation of preschool curriculum activities.}

\begin{tabular}{lll} 
Socio-Emotional Development Activities & Weighted Mean & Interpretation \\
\hline Physical Development Activities & & \\
Personal-Social Development Activities & 4.73 & VH \\
Cognitive Development Activities & 4.64 & VH \\
Creative-Aesthetic Development Activities & 4.18 & VH \\
Socio-Emotional Development Activities & 4.52 & $\mathrm{H}$ \\
Overall Weighted Mean & 4.53 & $\mathrm{VH}$ \\
\hline
\end{tabular}

VH - Very High, H - High

\section{Conclusion and Recommendations}

The teachers perceived some levels of effective implementation of the physical, cognitive, personal-social, and socioemotional aspects of the early childhood education curriculum. Teachers were able to teach the preschoolers how to develop and take care of their physical bodies, relate themselves to others especially to classmates and teachers, develop their thinking skills through play and interaction, appreciate beauty and order, and adjust to school life and to the people around them. Relative to other development aspects of preschools, creative-aesthetic development activities have to be given more attention by teachers. Class activities related to creativity, beauty and order have to be improved.

For the full implementation of the curriculum, preschool teachers have to seriously consider possessing the qualification and adequate preparations, and these can be obtained by giving the teachers more opportunities to attend trainings and seminars relative to Early Childhood Education instruction, and by hiring qualified 
teachers to teach Preschool Education specifically BEED graduates majoring Early Childhood Education or its equivalent.

\section{Acknowledgment}

The researcher would like to acknowledge the following individuals who have helped him in this scientific endeavor. Worth to mention are Dr. Karen Belina F. De Leon, President, Misamis University, Ozamiz City; Dr. Mildred M. Garcia, Director for Research of the University; and Miraflor T. Jomuad.

\section{Literature Cited}

Anderson, R. J. Evans, I. M., \& Harvey, S. T. (2012). Insider views of the emotional climate of the classroom: What New Zealand children tell us about their teachers' feelings. Journal of Research in Childhood Education, 26, 199-220.

Bilbao, P. P., Corpus, B. B., Llagas, A. T., \& Salandanan, G. G. (2006). The Teaching Profession. Quezon City: Lorimar Publishing Inc.

Binder, M. \& Kotsopoulus, S. (2011). Multimodal literacy narratives: Weaving threads of young children's identity through the arts. Journal of Research in Childhood Education, 25, 339-363.

Conyers, J. (2012). My very own imagination library. Childhood Education, 88(4), 221-231.

Crabb, P. B., \& Marciano, D. L. (2011). Representations of material culture and gender in award-winning children's books: A 20-years follow-up. Childhood Education, 25, 390-398.

Di Santo, A. (2012). Promoting preschool literacy: A Family Literacy Program for Homeless Mothers and Their Children. Childhood Education, 88(4), 232-240. 
Ernest, J. M. (2012). Evaluating large-scale studies to accurately appraise children's performance. Journal of Research in Childhood Education, 26, 40-56.

Freeman, R., \& Karlsson, F. dr. M. (2012). Strategies for learning experiences in family child care. Childhood Education, 88(2), 8190.

Glazzard, J., Chadwick, D., Webster, A., and Percival, J. (2010). Assessment for learning in the early years foundation stage. London: Sage.

Holmes, K., Homes, S. V., \& Watts, K. (2012). A descriptive study on the use of materials in vocabulary. Journal of Research in Childhood Education, 26, 237-248.

Horn, M. L. V., Karlin, E., \& Kamey, S. (2012). Effects of developmentally appropriate practices on social skills and problem behaviors in $1^{\text {st }}$ through $3^{\text {rd }}$ grades. Journal of Research in Childhood Education, 26, 18-39.

Jacob, S. W., Wadlington, E., \& Enloe, A. (2012). Emotional Intelligences: A missing link in educating our youth. Childhood Education, 88(4), 272-273.

Kohler, M., Kildo, J., \& Christensen, L. M. (2012). What is the Value of Play? Childhood Education, 88(3), 201-204.

Lynch, M. \& Batal, M., (2012). Child care providers' strategies for supporting healthy eating. A qualitative approach. Childhood Education, 26, 107-121.

Ma, X., Shen, J., \& Kavanaugh, A., (2011). Effects of quality improvement system for child care centers. Childhood Education, $25,399-414$.

Mawson, B. (2011). Children's leadership strategies in early childhood. Childhood Education, 25, 327-338. 
Mcafee, O., \& Leong, D. J. (2011). Assessing and Guiding Young Children's Development and Learning. Boston: Pearson.

McCray, J. S. \& Chen, J. Q. (2012). Pedagogical content knowledge for preschool mathematics: Construct validity of a new teacher interview. Journal of Reserch in Childhood Education, 26(3), 291307.

Mckie, B. K., ManswellButty, J., \& Green, R. D. (2012). Reading, reasoning, and literacy: Strategies for early childhood education from the analysis of classroom observations. Early Childhood Education Journal, 40(1), 55-61. doi:http://dx.doi.org/10.1007 /s10643-011-0489-2

Parks, A. N., \& Rhoads, S. B. (2012). Overly scripted: Exploring the impact of a scripted literacy curriculum on a preschool teachers' instructional practices in mathematics. Journal of Research in Childhood Education, 26, 308-324.

Patterson, C. J. (2008). Child Developments. New York: McGraw Hill.

Rooprarine, J. L., \& Johnson, J. E., (2009). Approaches to Early Childhood Education. New Jersey: Pearson.

Salmon, A. K. \& Lucas, T. (2011). Exploring young children's conceptions about thinking. Childhood Education, 25, 364-375.

Seay, S. (2012). Profile of a city. Childhood Education, 88 (4), 241247.

Yopp, H. K., \& Yopp, R. H. (2000). Supporting phonemic awareness development in the classroom. The Readi 